\title{
Alcohol Consumption in Urban Settings in the Surrounding Area of a University in Bogotá. Results of a Pilot Study
}

\section{Consumo de alcohol en entornos urbanos alrededor de una universidad en Bogotá. Resultados de un estudio piloto}

Received: 29 July 2018 | Accepted: 11 October 2018

\author{
Juan Nicolás Pavajeau ${ }^{a}$ \\ Pontificia Universidad Javeriana, Colombia \\ Daniela Arias ${ }^{b}$ \\ Pontificia Universidad Javeriana, Colombia \\ María Camila Echeverría ${ }^{c}$ \\ Pontificia Universidad Javeriana, Colombia \\ Paula Aranguren ${ }^{\mathrm{d}}$ \\ Pontificia Universidad Javeriana, Colombia \\ Luisa Natalia GutiÉrrez \\ Pontificia Universidad Javeriana, Colombia \\ Luis Fernando Gómez Gutiérrez \\ Pontificia Universidad Javeriana, Bogotá, Colombia, \\ Colombia \\ José David Pinzón ${ }^{g}$ \\ Universidad Jorge Tadeo Lozano, Colombia
}

\footnotetext{
a Student, School of Medicine, Pontificia Universidad Javeriana, Bogotá, Colombia.

b Student, School of Medicine, Pontificia Universidad Javeriana, Bogotá, Colombia.

c Student, School of Medicine, Pontificia Universidad Javeriana, Bogotá, Colombia.

d Student, School of Medicine, Pontificia Universidad Javeriana, Bogotá, Colombia.

e Student, School of Medicine, Pontificia Universidad Javeriana, Bogotá, Colombia.

f Professor of the Department of Preventive and Social Medicine, School of Medicine, Pontificia Universidad Javeriana, Bogotá, Colombia.

$\mathrm{g}$ Professor of the School of Arts and Design, Universidad Jorge Tadeo Lozano, Bogotá, Colombia.
}

How to cite: Pavajeau JN, Arias D, Echeverría MC, Aranguren P, Gutiérrez LN, Gómez Gutiérrez LF, Pinzón JD. Alcohol Consumption in Urban Settings in the surrounding area of a University in Bogotá. Results of a Pilot Study. Univ. Med. 2019;60(1). doi: https://doi.org/10.11144/Javeriana. umed60-1.caeu

\begin{abstract}
Objective: The aim of this pilot study was to characterize the perceptions of university students regarding alcohol consumption and the availability of alcohol outlets in the urban perimeter of a university in Bogota. Methods: A mixed cross-sectional study was conducted among 201 undergraduate students aged 18-27 using a non-probabilistic sampling design. The perceptions regarding alcohol consumption in the surrounding area of the university were assessed via a self-reported questionnaire. Geographic Information Systems were used to identify the alcohol outlets. Results: Of the students surveyed, 66\% reported that they had consumed alcohol in the surrounding area of the university, and $26 \%$ agreed with the implementation of strict measures to control alcohol consumption, with a higher percentage in those who did not consume alcohol (41.2\%). The geographic analysis showed that several urban attributes were correlated with alcohol consumption. Conclusion: The results of this study show the potential influence that the availability of alcohol outlets near a university campus has as a public health issue. Further studies should be conducted in order to better understand the links between urban contexts near universities and alcohol consumption. Keywords alcohol supply and distribution; alcohol; urban health.
\end{abstract}




\section{RESUMEN}

Introducción: El objetivo de este estudio piloto fue caracterizar las percepciones de estudiantes universitarios sobre el consumo de alcohol y la disponibilidad de establecimientos que expenden licor en el perímetro urbano de una universidad de Bogotá. Métodos: Se llevó a cabo un estudio transversal y mixto en 201 estudiantes seleccionados por una muestra no probabilística. Se usó una encuesta autodiligenciada para evaluar percepciones respecto al consumo de alcohol alrededor de la universidad, y sistemas de información geográfica para identificar los establecimientos que vendían alcohol. Resultados: El 66\% de los participantes informó haber consumido alcohol alrededor del campus universitario. El 26\% se mostraba de acuerdo o muy de acuerdo con la implementación de medidas estrictas para restringir el consumo, siendo mayor en personas que no consumieron (41,2\%). El análisis geográfico encontró un patrón de concentración de oferta y consumo de alcohol en las inmediaciones de la universidad. Conclusión: Este estudio muestra la potencial influencia que tiene la oferta y consumo de alcohol alrededor de un campus universitario para la salud pública. Se deben llevar a cabo estudios complementarios para entender, de mejor manera, posibles vínculos entre contextos urbanos universitarios y consumo de alcohol.

Palabras clave

alcohol; salud urbana; estudiantes.

\section{Introduction}

Alcohol abuse is a major public health problem that is associated with $5.9 \%$ of all deaths worldwide (1). Excessive alcohol intake among young people is positively linked to an increased risk of traffic accidents, sexually transmitted diseases and suicide (2). In 2013, the prevalence of alcohol abuse in Colombia was $38.1 \%$ among young people aged 18-24, who represent the most important age group of the country's university population (3). A study carried out in undergraduate students of the Pontificia Universidad Javeriana (PUJ) in Bogotá found that $21.2 \%$ of the participants reported having drunk at least one glass of liquor inside the campus (4).

The risk derived from alcohol consumption is related to sociodemographic characteristics such as age and sex, and factors such as the hours in which it is consumed and the availability of alcohol outlets. According to data from the World Health Organization, the region of the Americas is among those with the highest prevalence alcohol abuse by adolescents (1).

The World Health Organization (WHO) has promoted the implementation of preventive measures to regulate alcohol consumption and reduce the disease burden caused by its intake. These measures include regulating of the number of alcohol outlets, to reduce their geographical density, and regulate the days and hours when alcohol can be sold $(1,5)$. The WHO also recommends establishing restrictive policies regarding consumption in public places and that advertising be regulated, as it has been shown to promote initiation or increase of consumption $(1,6)$. In addition, universities such as the PUJ, consider that repeated alcohol consumption inside the campus is a serious disciplinary offence that has important consequences on the student's disciplinary record (7).

Two studies conducted in New Zealand found a positive association between the geographical density of alcohol outlets in the vicinity and excessive alcohol consumption in the adolescent and young adult population $(8,9)$. Studies conducted in Europe (10), North America (11) and Australia (12) have shown similar results. However, there are no reports on this subject in urban contexts near universities in Latin America.

In the literature published in Colombia on alcohol consumption in university environments, Molano et al. (12) described how alcohol consumption is facilitated by ease of acquisition. They mention that consumption begins during school years and is accentuated during the university period. Bethancourth-Zambrano et al. (13) recognize alcohol consumption among university students as a public health problem, with a $97.5 \%$ consumption prevalence. Rodríguez et al. (14) also described that the prevalence of risk of alcoholism in students of a university in Medellín, according to the CAGE test, was $8 \%$, higher in the population aged 16-24 with the highest risk of alcoholism (15).

In 2011, the Mayor's Office of Bogotá established restrictive measures "[...] for the sale and consumption of intoxicating liquors in commercial establishments adjacent to 
universities" (15). In this context, conducting a pilot study that characterizes the presence of alcohol outlets in the surrounding area of a university, as well as the perceptions that students have about this problem, could generate hypotheses that guide the realization of studies on the subject. The objective of this study was to characterize the perceptions of undergraduate students regarding alcohol consumption and the availability of alcohol outlets in the surrounding area of a private university in Bogotá.

\section{Methods}

A cross-sectional and mixed descriptive pilot study was carried out, in which university students were asked to complete a selfadministered survey; a fieldwork was also done to identify the geographical location of alcohol outlets in a defined area in the surrounding area of the Pontificia Universidad Javeriana (PUJ) in Bogotá. This data was correlated with the areas where the students indicated that they had consumed alcohol during the first academic period of 2015. The perceptions of the students on the subject were also evaluated. The Ethics Committee of the Hospital Universitario San Ignacio evaluated and approved the study protocol.

Conducting a mixed study allows us to address a research question that requires using different data sources in order to make a comprehensive analysis (16). Because of this, and to facilitate data analysis, two components were established according to the nature of the measured variables: a perception component and a geographical variable component.

\section{Component to evaluate perceptions}

A non-probabilistic sampling was carried out to carry out a survey of in undergraduate students from four faculties of the PUJ, which were chosen based on a 2012 study (4). We selected the faculties with more dissimilar consumption of alcohol: Political Science and International
Relations, Medicine, Social Sciences and Fine Arts.

The inclusion criterion was to be an active undergraduate student of the PUJ, currently studying Political Science and International Relations, Medicine, Social Sciences or Fine Arts. The exclusion criterion was to be a minor. All the participants agreed to complete the survey.

Each of the participants answered a self-administered survey that included basic sociodemographic variables and perceptions about the urban environment in the surrounding area of the university related to alcohol consumption. Before applying the survey, and in order to assess its clarity and the relevance of its content, several cognitive interviews were conducted using the survey. Feedback was received to make the survey clear and easy to use.

The sociodemographic variables were: identification of the student, age, sex, faculty and semester. Additionally, the survey included questions about alcohol consumption in the surrounding area of the university campus during the current semester (first period of 2015), and about the area where it happened, using a map that was printed on each survey.

Perception variables inquired about three basic aspects: degree of agreement that alcohol consumption is allowed in the surrounding area of the university, degree of agreement that measures are implemented to control consumption, and perception on how consumption affects the security in the area. The response options were structured in 4-option Likert scales.

The Stata 12 program was used to perform an univariate and bivariate data analysis, taking as variables the fact of having consumed alcohol in the areas near the PUJ during the first semester of 2015, and the other individual variables (sex, age, faculty and semester), reported in percentages. In the case of perception variables, we collapsed the categories: "agree" and "totally agree", and on the other hand, "disagree" and "totally disagree". 
Component to evaluate geographic characteristics

For the geographic component, the researchers selected an area close to the PUJ campus, taking into account the main streets that delimit it, and the possible social and urban barriers. The south limit was the 39th street and the north limit was the 45th street; the east limit was the seventh street and the west limit the Caracas Avenue. The researchers used their judgment to establish this delimitation, since these are the main streets that form a barrier, and this is the most frequented zone by the students, given that there are commercial establishments, restaurants, and by the access to means of public transport.

The area was visited to identify the alcohol outlets, and they were entered into a geographic positioning system to generate a Kernel density map; this made it possible to identify the areas with the highest number of these establishments. Subsequently, a new Kernel density map was generated with the establishments in which the students reported having consumed alcohol. The survey contained a map that included the area of the university campus and, additionally, a small area to the east of the seventh street. Finally, the Kernel densities of the alcohol outlets and those in which the students reported having consumed were contrasted in a map. The ArcGIS program was used for the geographic analysis.

\section{Results}

Table 1 shows the univariate distribution of the sociodemographic characteristics and the perception variables of the population studied.
Table 1

Characteristics of the population studied study population

\begin{tabular}{|c|c|c|}
\hline Variables & $\mathbf{N}$ & $\begin{array}{l}\text { Percentage } \\
\text { mean (SD) }\end{array}$ \\
\hline \multicolumn{3}{|r|}{ 年 } \\
\hline Male & 77 & 38.30 \\
\hline Female & 124 & 61.70 \\
\hline Age in years & 201 & $20.4(1.9)$ \\
\hline \multicolumn{3}{|l|}{ Age groups (years) } \\
\hline $18-20$ & 121 & 60.20 \\
\hline $21-27$ & 80 & 39.80 \\
\hline \multicolumn{3}{|l|}{ Faculty } \\
\hline Medicine & 49 & 24.40 \\
\hline Social Sciences & 50 & 24.90 \\
\hline Fine Arts & 56 & 27.90 \\
\hline Political Science and Intemational Relations & 46 & 22.90 \\
\hline \multicolumn{3}{|l|}{ Semester } \\
\hline First to fourth & 86 & 43.40 \\
\hline Fifth & 63 & 31.80 \\
\hline Sixth to twelfth & 49 & 24.80 \\
\hline \multicolumn{3}{|c|}{$\begin{array}{l}\begin{array}{l}\text { Degree of agreement with the consumption of } \\
\text { in the surrounding area of the PUJ }\end{array} \\
\end{array}$} \\
\hline I totally agree & 46 & 23.10 \\
\hline I agree & 115 & 57.80 \\
\hline I disagree & 33 & 16.60 \\
\hline I totally disagree & 5 & 2.50 \\
\hline Missing data & 2 & - \\
\hline \multicolumn{3}{|c|}{$\begin{array}{l}\text { Degree of agreement with the implementation of strict measures to } \\
\text { restrict alcohol consumption in the surrounding area of universities }\end{array}$} \\
\hline I totally agree & 9 & 4.50 \\
\hline I agree & 45 & 22.40 \\
\hline I disagree & 111 & 55.20 \\
\hline I totally disagree & 36 & 17.90 \\
\hline Missing data & 0 & - \\
\hline \multicolumn{3}{|c|}{$\begin{array}{l}\text { Perception of the impact of alcohol consumption on the security } \\
\text { in the area near the university }\end{array}$} \\
\hline A very high impact & 15 & 7.6 \\
\hline A high impact & 68 & 34.30 \\
\hline A little impact & 104 & 52.50 \\
\hline A very little impact & 11 & 5.60 \\
\hline Missing data & 3 & - \\
\hline
\end{tabular}

Approximately $62 \%$ of the participants were women. The average age was 20.4 years. $43.4 \%$ of the participants were from first to fourth semester, and $24.8 \%$ were from sixth to twelfth semester. Regarding the question on allowing alcohol consumption in the surrounding area of the PUJ, 23.1\% answered "I totally agree", and $57.8 \%$ answered "I agree". More than half of the participants disagreed with the implementation of strict measures to restrict consumption $(55.2 \%)$, and most perceived that the consumption of alcoholic beverages has little impact on the security of the area (52.5\%).

Sixty-six point seven percent reported having consumed alcohol in the surrounding area of the university. This indicator had higher values in male students $(83.1 \%)$, in those belonging to the $21-27$ years age group (75\%), in those from sixth to twelfth semester $(75.5 \%)$, and in the students of the Faculty of Social Sciences (76\%) (Table 2). 
Table 2

Proportion of students who consumed alcohol in the surrounding area of the university, according to the selected characteristics

\begin{tabular}{|c|c|}
\hline Variables & $\begin{array}{l}\text { Percentage of } \\
\text { students who } \\
\text { consumed alcohol }\end{array}$ \\
\hline \multicolumn{2}{|l|}{ Sex } \\
\hline Male & 83.1 \\
\hline Female & 56.5 \\
\hline \multicolumn{2}{|l|}{ Age groups } \\
\hline $18-20$ & 61.2 \\
\hline $21-27$ & 75 \\
\hline \multicolumn{2}{|l|}{ Semester } \\
\hline First to fourth & 61.6 \\
\hline Fifth & 68.3 \\
\hline Sixth to twelfth & 78.5 \\
\hline \multicolumn{2}{|l|}{ Faculty } \\
\hline Medicine & 65.3 \\
\hline $\begin{array}{l}\text { Political Science and } \\
\text { Intermational Relations }\end{array}$ & 52.2 \\
\hline Total number of participants & 66.7 \\
\hline
\end{tabular}

Table 3 shows the distribution of perceptions on alcohol consumption, according to the variables selected in the study.

Table 3

Perceptions on alcohol consumption, in percentages, according to the selected variables $(n=201)$

\begin{tabular}{|c|c|c|c|}
\hline Variables & $\begin{array}{l}\text { Disagreement with } \\
\text { alcohol consumption } \\
\text { in the surrounding } \\
\text { area of the PUJ }\end{array}$ & 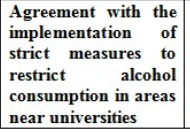 & $\begin{array}{l}\text { Perception of high } \\
\text { impact on the } \\
\text { security of areas } \\
\text { near the } \\
\text { university }\end{array}$ \\
\hline \multicolumn{4}{|c|}{ 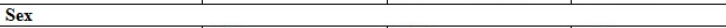 } \\
\hline Male & 15.6 & 24.7 & 38.2 \\
\hline Female & 21.3 & 28.2 & 44.3 \\
\hline \multicolumn{4}{|l|}{ Age groups } \\
\hline $18-20$ & 20 & 3.14 & 47.9 \\
\hline $21-27$ & 17.7 & 20 & 32.9 \\
\hline \multicolumn{4}{|l|}{ Semester } \\
\hline $1-4$ & 15.3 & \begin{tabular}{|l|l|}
26.7 \\
\end{tabular} & 45.9 \\
\hline 5 & 23.8 & 33.3 & 43.6 \\
\hline $6-12$ & 20.4 & 20.4 & 31.3 \\
\hline \multicolumn{4}{|l|}{ Faculty } \\
\hline Medicine & 26.5 & \begin{tabular}{|l|l|}
38.8 \\
\end{tabular} & 50 \\
\hline Social Sciences & 20 & 22 & 32.7 \\
\hline Fine Arts & 10.9 & 17.9 & 27.3 \\
\hline $\begin{array}{l}\text { Political Science and } \\
\text { Intermational Relations }\end{array}$ & 20 & 30.4 & 60.9 \\
\hline \multicolumn{4}{|c|}{ Reported having consumed alcoholic beverages in the surrounding area of the university } \\
\hline Yes & 8.2 & 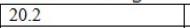 & 33.8 \\
\hline No & 41.5 & 40.3 & 58.5 \\
\hline $\begin{array}{l}\text { Total number of } \\
\text { participants }\end{array}$ & 19.1 & 26.9 & 41.9 \\
\hline
\end{tabular}

Nineteen point one percent of the participants answered "I totally disagree" or "I disagree" with alcohol consumption in the surrounding area of the university. This proportion was higher in women $(21.3 \%)$ than in men $(15.6 \%)$, being higher in students from sixth to twelfth semester (20.4\%) than in those from first to fourth semester $(15.3 \%)$. In this indicator, the most dissimilar results were between the faculties of Medicine (26.5\%) and Fine Arts (10.9\%). It should be noted that among the participants who reported having consumed alcoholic beverages in the surrounding area of the university there is a considerably smaller percentage that disagrees with alcohol consumption (8.2\%) than in those who reported not having consumed alcoholic beverages (41.5\%).

Only $26.9 \%$ of respondents answered "I agree" or "I totally agree" with the implementation of strict measures to restrict alcohol consumption in areas near the university; the highest proportion was of women $(28.2 \%)$ and from the $18-20$ years age group (31.4\%). In addition, the faculty that agreed most with the implementation of strict measures was Medicine (38.8\%), and the one that agreed least was Fine Arts (17.9\%).

Of the total number of respondents, $41.9 \%$ reported perceiving that alcohol consumption in the surrounding area of the university had a high or very high impact on the security of the area, being higher in women $(44.3 \%)$, in the $18-20$ years age group (47.9\%) and from the Faculty of Political Science (60.9\%).

Figure 1 shows the areas in which the participants reported having consumed alcohol at some time. The most frequent areas of consumption were those close to public parks and those located on the usual routes to access public transport, such as Transmilenio, which are within walking distance from the main entrance of the university. 


\section{Figure 1}

Report of alcohol consumption by students of the PUJ in the areas near the university campus

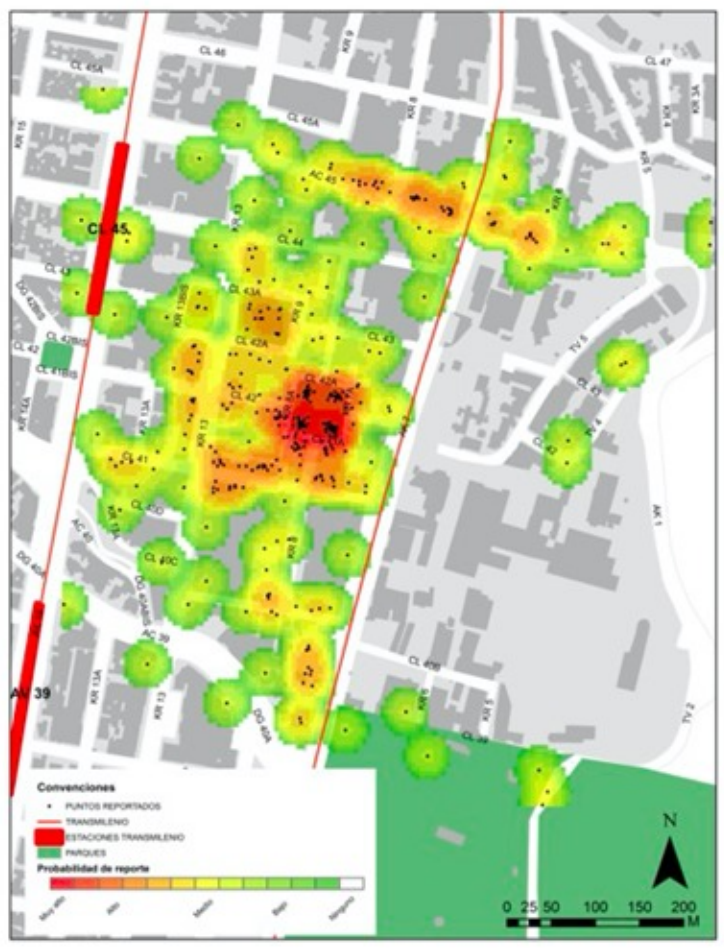

Figure 2 shows a contrast of the areas in which consumption is reported with the field exploration carried out to look for alcohol outlets. It can be observed that the alcohol outlets in the studied area were distributed in small agglomerations of commercial establishments of various types.
Figure 2

Contrast of the report of alcohol consumption by PUJ students in the surrounding area of the campus with the density of alcohol outlets

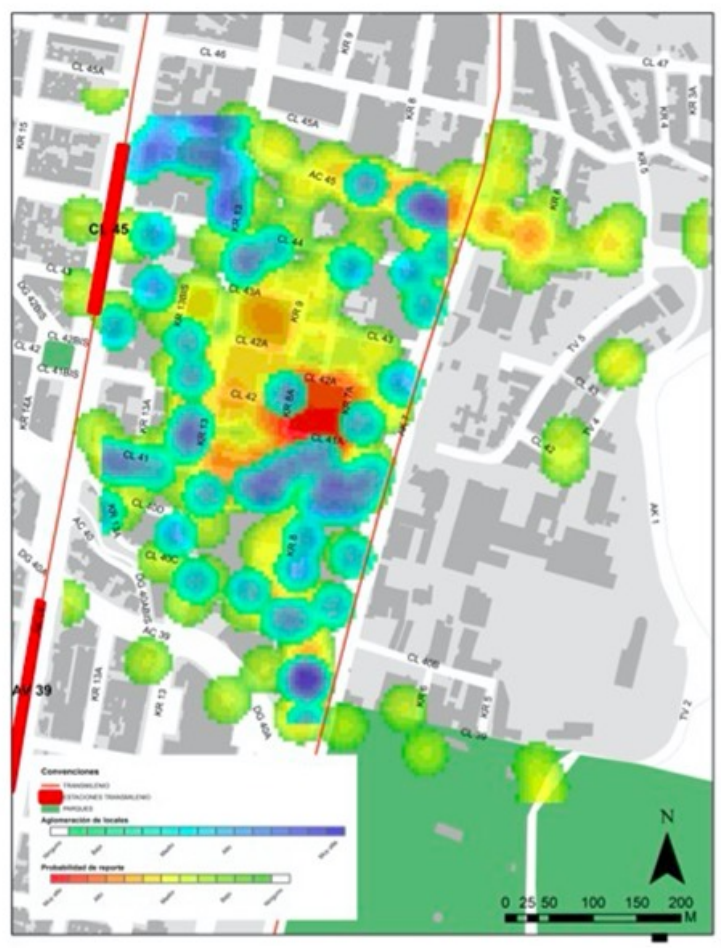

\section{Discussion}

This pilot study addressed the possibilities offered by mixed approaches in urban research related to alcohol consumption. The results suggest that alcohol consumption is very high in the university population. They also suggest that there could be links between consumption and the nearby urban contexts. On the other hand, this study presents a self-perception component on alcohol consumption in places near the university campus and on the measures that restrict it, components that had not been reviewed in previous studies.

Two basic aspects support the relevance of this preliminary exploration. First, it highlights the usefulness of geographic information systems to establish the links between the different attributes of social and physical urban environments and alcohol consumption by 
the university population. This tool provides information that transcends the focus centered on establishing the individual characteristics of alcohol consumers, by identifying attributes of the urban context, such as the socioeconomic position of the neighborhood, proximity to educational centers, geographical density of alcohol outlets and social capital.

On the other hand, the use of mixed methods allows to coherently integrate the methodological components of a study; this offers a more comprehensive perspective of the problem of excessive alcohol consumption in the university population, which allows for the orientation of public policies involving various degrees of intervention (16).

Several limitations were identified in this pilot study. First, its cross-sectional methodological design does not allow establishing causal relationships. On the other hand, the small size of the sample and its non-probabilistic design do not allow making statistical inferences to the student population of the selected university. It should be noted that $62 \%$ of the people surveyed were women, whose consumption and perceptions are different from those of men. It is also important to note that while $66 \%$ of participants reported having consumed alcohol near the campus, only $26.9 \%$ agreeded with the possibility to implement regulations to restrict consumption; we consider that this factor can contribute negatively to the implementation of new policies and to the compliance with the existing ones. Finally, the results only apply to the university population selected in the non-probabilistic sample. In this sense, the need arises to carry out studies that compare different university and urban contexts that may be related to alcohol consumption.

Despite these limitations, this pilot study can provide guidance in the formulation and implementation of public and organizational policies aimed at preventing excessive alcohol consumption. This with a view to better regulation of alcohol outlets, considering that its proximity to educational institutions can encourage consumption.

\section{References}

1. World Health Organization. Global status report on alcohol and health 2014. Geneva: WHO; 2014.

2. Ellickson PL, Collins RL, Hambarsoomians K, McCaffrey DF. Does alcohol advertising promote adolescent drinking?: Results from a longitudinal assessment. Addiction. 2005; $100(2): 235-46$.

3. Ministerio de Justicia, Ministerio de Salud y Protección Social. Estudio Nacional de Consumo de Sustancias Psicoactivas en Colombia 2013. Bogotá; 2013.

4. Pontificia Universidad Javeriana, Programa de Universidad Saludable. Prevalencia de factores de riesgo comportamentales en estudiantes de pregrado de la Pontificia Universidad Javeriana. Bogotá; 2012.

5. Anderson P, de Bruijn A, Angus K, Gordon R, Hastings G. Impact of alcohol advertising and media exposure on adolescent alcohol use: a systematic review of longitudinal studies. Alcohol Alcohol. 2009;44(3):229-43.

6. Ahem J, Margerison-Zilko C, Hubbard A, Galea S. Alcohol outlets and binge drinking in urban neighborhoods: the implications of nonlinearity for intervention and policy. Am J Public Health. 2013;103:e81-7.

7. Ayuka F, Barnett R, Pearce J. Neighborhood availability of alcohol outlets and hazardous alcohol consumption in New Zealand. Health Place. 2014;29:186-99.

8. Huckle T, Huakau J, Sweetsur P, Huisman O, Casswell S. Density of alcohol outlets and teenage drinking: living in an alcogenic environment is associated with higher consumption 
in a metropolitan setting. Addiction. 2008;103:1614-21.

9. Halonen JI, Kivimaki M, Virtanen M, Pentti J, Subramanian SV, Kawachi I, Vahtera J. Proximiy of off-premise alcohol outlets and heavy alcohol consumption: a cohort study. Drug Alcohol Depend. 2013;132:295-300.

10. Wilsnack R, Wilsnack S, Kristjanson A, Vogeltanz N, Gmel G. Gender and alcohol consumption: patterns from the multinational genacis project. Addiction [internet]. 2009 [cited 2015 May 29];104(9):1487-500. Avalaible at: http://www.ncbi.nlm.nih. gov/pmc/articles/PMC2844334/pdf/ni hms134605.pdf.

11. Kavanagh AM, Kelly MT, Kmjacki L, Thornton L, Jolley D, Subramanian SV, Turrel G, Bentley RJ. Access to alcohol outlets and harmful alcohol consumption: a multi-level study in Melbourne, Australia. Addiction. 2011;106:1772-9.

12. Molano Tobar N, Molano Tobar

D. Concepción frente al consumo de alcohol en jóvenes de la Universidad del Cauca. Univ Salud. 2016;18(3):532-40. doi: http://dx.doi.o rg/10.22267/rus.161803.58.

13. Betancourth-Zambrano S, TacánBastidas L, Córdoba-Paz EG. Consumo de alcohol en estudiantes universitarios colombianos. Univ Salud. 2017;19(1):37-50. doi: https://d oi.org/10.22267/rus.171901.67.

14. Rodríguez Gásquez MA, et al. Consumo de alcohol y tabaco en estudiantes de pregrado de una universidad privada de Medellín, 2007. Invest Educ Enferm. 2009;27(1):60-8.

15. Decreto 484 de 2011/3 de noviembre, por el cual se restringe el horario para el expendio y consumo de licor y bebidas embriagantes en establecimientos de comercio aledaños a los centros educativos universitarios, y se dictan otras disposiciones [internet]. Avalaible at: http://www.alcaldiabogota.gov.co/si sjur/normas/Norma1.jsp?i $=44547$.

16. Cresswell JP. Designing and conducting mixed methods research. Thousand Oaks, CA: Sage; 2007.

\section{Annex 1. Survey \\ Pontificia Universidad Javeriana. School of Medicine}

Perceptions about alcohol consumption among students of the PUJ

This survey is being done by second-semester students of Medicine. Its objective is to characterize the density and distance of the alcohol outlets in the surrounding area of the PUJ, as well as the perceptions of the students on alcohol consumption.

Your participation in this survey is voluntary and anonymous, and the data provided will be treated confidentially. If you do not want to complete it, you can return the form.

This survey is part of the academic work of undergraduate students of Medicine. The information collected will be restricted exclusively to educational purposes; the questions in no case correspond to positions or official interests of the PUJ.
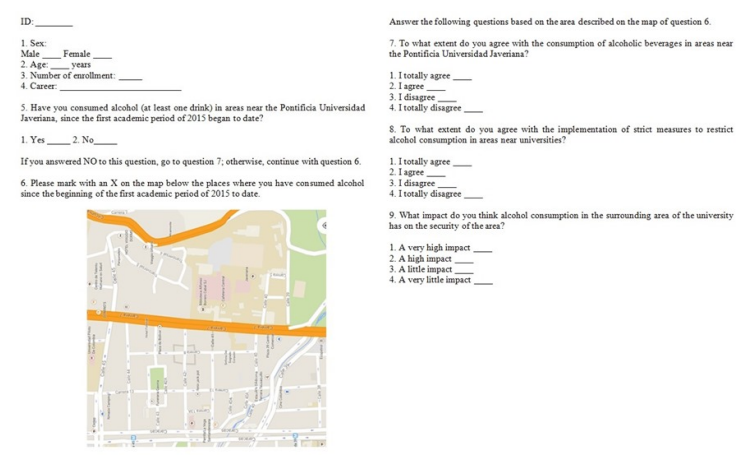